\title{
Policies and public opinion towards immigration: the Spanish case ${ }^{*}$
}

\begin{abstract}
:
By tackling negative opinions towards immigration we can create a basis to orientate policies that seek to reduce them. My purpose is to highlight that the analysis of immigration in Spain exemplifies a clear link between policies and public opinion. It is this link that is at the basis of what I will call the ambivalence of Spanish public opinion, when border and integration issues are compared.
\end{abstract}

Keywords: Public opinion, Spain, immigration policies, governance, negative perception, citizen's attitude

\section{Introduction}

Immigration is a subject that gives rise to controversial debate, generates administrative ambivalence, fragments and polarises society, and constantly places the capacity of governance in doubt. We must assume the inevitable existence of negative attitudes towards immigration as being a semi-permanent fact of the political culture in host countries. Practically all influential political surveys and reports highlight the negative perception generated by immigration. ${ }^{1}$

The purpose of this article is to highlight that the analysis of immigration in Spain exemplifies there is a clear link between policies and public opinion. It is this relationship, I will argue, that is at the basis of what I will call the ambivalence of Spanish public opinion, when border and integration issues are compared. 
When dealing with a reflection on the link between public opinion and immigration we find ourselves under the premise that it is not so much the facts but the interpretations thereof that are of interest (Zapata-Barrero 2004a). In hermeneutic terms, immigration is an interpretable reality where perceptions determine attitudes and behaviour. $^{2}$

When considering the evaluations that citizens make on immigration-related matters, we unavoidably divide attitudes into positive/negative. ${ }^{3}$ These attitudes have a practical component for those who translate data. It tells them if there is support for specific policies. Hence, attitudes towards immigration should not be interpreted only in the framework of the relationship between the citizen and the immigrant, but in a framework in which it is not so much the phenomenon of immigration that is evaluated but rather the government's policies. It is at this point that the ambivalence of Spanish public opinion towards immigrants becomes evident.

I shall expose this argument in three sections. Firstly, I will briefly review existing literature on negative public opinion, with special emphasis on the perceptions of immigration policies implemented (section 1). Then I will identify the categories that characterise most the negative opinion in Spain taking the government-run CIS (Centro de Investigaciones Sociológicas) surveys as a main data source (section 2). I will end with a conclusion proposing further research to understand the ambivalence of public opinion through what I will suggest to call as the governance hypothesis (section 3).

\section{The state of the question: Can public opinion on immigration be predicted?}


Recent studies show that there are some variables that condition negative perception and highlight their predictive value. ${ }^{4}$ A list of these variables and correlations can help us design a profile. However, there is a danger of considering them in an isolated fashion, as irrevocable anticipators of negative attitudes when the reality shows that these variables are activated in certain contexts and situations favouring certain correlations. Four significant categories exist. The category of personal characteristics says that a whole set of variables exists that act as determining factors of anti-immigrant sentiment: age; education; earnings; labour status; ideology (left/right wing) (Citrin et al. 1997; Burns and Gimpel 2000; Coenders et. al. 2004; Kessler and Freeman 2005).

The instrumental category and that of self-interest which follows a socioeconomic logic expresses the idea that perceptions are based on self-interest calculations (Kessler and Freeman 2005). It highlights the existence of a link between material worries and anti-immigrant opinions (Citrin et-al. 1997, pp. 863). At this point, the context of competition is what plays the most determining role in activating a negative attitude (Fetzer 2000). In this framework, the power-threat sentiment plays a role. A group with greater power (for example autochthonous workers) is more susceptible to being hostile if another exogenous group comes close and grows, with the consequent perception of a threat leading to a reduction of economic and social privileges (Oliver and Wong 2003, pp. 568). Along these same lines, but inverting the argument, Lahav (2004b, pp. 1169) also points out that it is not so much unemployment that is significant as the fear of losing one's job in a negative labour market situation. Although low economic level and labour status usually have an explanatory value, correlations exist that help to specify this variable. Especially on the sectorial level, manual and industrial workers tend to show more opposition to immigration (Kessler 
and Freeman 2005, pp. 826-827). This is due especially to the fact that, in situations of work sector competition, salaries tend to decrease and the access of immigrants tends to increase (Borjas 1999).

The symbolic and emotive category, following a logic of prejudice and identity, usually affects its predictive function in its two dimensions: the rational and the affective/emotional. However it is the emotional dimension especially that has greater influence in orienting negative attitudes. Perception is based on long-term affective or cognitive predispositions. Hostility towards the out-group is linked to the preferences of the in-group. Thus, a social logic characteristic of racist discourse (in terms of Van Dijk 2003a, 2003b) develops, of a negative-others and positive-us. Although some studies exist that insist that identity is not as determining as other socioeconomic factors in predicting negative opinions (Luedtke 2005), what is true is that it is proven, especially in comparative studies that take the Eurobarometer as a basis, that national identity is an important variable in explaining negative opinion (Lahav 2004b; Citrin et al. 2001).

The fourth category is based on the hypothesis of contact between citizens and immigrants, mainly refered to on at least four levels: personal contact; contact at work; residential; neighbourhood proximity (block of flats, street, district, town); and regional location (Mediterranean border, Northern Europe, recent joining the EU accession, etc.). ${ }^{5}$

Finally, we reach the category related to the perceptions of immigration policies implemented, which will frame our analysis of Spain. Although at the beginning it was assumed that a link between attitudes and policies existed (it was assumed that a negative perception necessarily generated support for restrictive immigration policies), today this relationship is not necessarily as strong. Therefore assumption must be 
questioned. For example, Simon and Lynch (1999) show that the desire to restrict immigration is not necessarily consistent with attitudes towards immigrants. Negative attitudes towards immigrants are usually also closely related with the cultural distance between groups of immigrants and the autochthonous population.

Within this framework, some studies analyse attitudes towards immigration taking into account the policies that are made, based on the premise that the political management of these has an effect on negative opinion. Hence we must recognise that the anxiety expressed by a significant number of people does correspond to governments' ability/capacity to accommodate them (Lahav 2004b, pp. 1170) and to manage the flows, rather than the current immigrant presence, or the media treatment given.

It is not necessarily true that there is a correlation between immigration policies and citizens' attitudes towards immigrants. In some comparative studies the conclusion is reached that despite the existence of policy differences, status and practices towards immigration, and differences in the number and accepted nationalities of origin, attitudes are very similar. The majority is always inclined to think that their country ought to allow fewer immigrants than the laws permit (Simon and Lynch 1999). But, if the matter is approached in terms of the results (outcomes) of policies, or in terms of the difference between objectives (inputs) and results (outputs), in order to evaluate what some call the gap between political demands and the results of the policies, ${ }^{6}$ the results between countries show greater differences to the extent that one can consider that the entry criteria followed by a government influences attitude. The transnational work by Bauer, Lofstrom and Zimmermann (2000) follows similiar lines. For them a correlation exists between the favourable sentiment towards immigration and the knowledge that their 
country selects immigrants according to their training (skills) and in accordance with labour market needs.

Taking the EU scope of his research, Lahav (2004a) insists that a correlation exists between attitudes towards immigration and the perception of policy results (policy outcomes). With this argument, he challenges several assumptions. Firstly, that people are more informed on immigration matters than is usually supposed, and that this information has several sides to it: the personal, self-interest side, the social, and the symbolic. Secondly, that people's public political preferences are more motivated by social interests than by self-interest. Thirdly, that political cooperation on this matter (between States but it could also be regarded between players, etc.) usually reflects the state of public opinion. This also implies rejecting the hypothesis that the relationship between immigrant flows and immigration policies should be looked at and that the policies/public opinion relationship should be looked at further.

Applying these arguments to the Spanish case I will show that the link between policies and public opinion not only is confirmed, but can help to understand what I will call the ambivalence of Spanish public opinion, when border and integration issues are compared.

\section{Spanish public opinion towards immigration: distinctive characteristics}

Initially it is significant that most Spanish literatures have the same methodological reaction: they start their analysis going over the number of immigrants. ${ }^{7}$ 
This leads us to think that the relationship between the number of immigrants and public perception is seen to be very close. We know, however, that this relationship is not so intuitive.

There are some supranational studies based on the results of the Eurobarometer showing that there is no such a link (Lahav 2004b; Citrin et al. 2001). What is significant is not so much the number of immigrants as the speed of migratory flows (Gimeno 2001). An increase in negative attitude is linked to the increase of $3.50 \%$ from 2000 to $2005 .^{8}$ The perception of the amount of immigrants must, therefore, be considered in relation to the frequency/speed of flows. This is a distinctive feature in Spain compared with other European countries. Another also widespread assumption is also true: attitudes form part of the study of the effects of immigration. It is these effects that have been the interest of the first studies on public opinion/immigration in Spain. We also know that it was under the VIth (1996-2000) and VIIth (2000-2004) legislatures, with the right wing Partido Popular in government, that negative public opinion was first linked to migratory flows. Politically it was assumed that "the more immigration, the higher the percentage of negative opinion". Studies in Spain have therefore worked under this conceptual framework generated by government policy itself.

If we look for arguments that distinguish Spanish public opinion, in addition to highlighting its tolerant nature (for example, Cea D’Ancona 2004), the analysis of responses show that Spanish citizens separate clearly issues relating to migratory flows and borders, from issues related to immigrant inclusion and integration (level where its tolerant nature is perceived). We must therefore concentrate on this level. 
Firstly we shall perform transversal analysis from March 1999 to October 2006, identifying the main peaks and interpreting them contextually. We shall see that legislative changes and periods of political innovation are the most likely to bring about higher negative attitudes. Then, in a second section, we shall develop the results of the fourth peak found (of November 2005), as it was the month that saw the introduction of immigration related questions into the Spanish Barometer.

\subsection{Development of immigration as a basic concern and relevant contextual} factors: 2000-2006

In Spain, the main sources of information are the Barometers of the Centro de Investigaciones Sociológicas (CIS). ${ }^{9}$ The questions on immigration start to become regular from $2000 .{ }^{10}$ This would mean that it was in this year that immigration entered the government's agenda. ${ }^{11}$

In the question about what people consider to be the three most important problems affecting the country, immigration becomes a permanent category starting from September 2000. Graph 1 gives an overview of the increasing importance of immigration as a problem. ${ }^{12}$

[Graph 1 about here]

There are several remarks to be made. Firstly, throughout the entire period, immigration is perceived as one of the most important problems in the country, along with unemployment, civil insecurity, terrorism, housing, and economic and political problems. Immigration is one of the nine most important problems mentioned and, on 
average, ranks fourth. Secondly, it is striking that since April 2005 immigration has been placed on the top three most important problems, reflecting a growing and consolidated concern about immigration from 2004 onwards. Since October 2005, immigration has been ranked second after unemployment and before terrorism, and in September 2006 it reached the first position for the first time. Thirdly, at least five peaks can be observed. ${ }^{13}$ The argument that is inferred is that border issues have played a significant explanatory role, and that there are several concrete factors that influence the "problematisation" of immigration: illegal aliens; changes in legislation and the perception of poor management of immigration (those without papers, flow management, etc.); specific conflicts related to exclusion that demand social and political positioning beyond the scope of the local administration where they occur; immigration policies by decree (especially regularisation/normalisation policies); and the reactive discourse of political parties (Zapata-Barrero 2007b and 2008b). All are ultimately linked to the legislative changes and the perception of ineffective management of flows. Following the research framework of this article, my argument is that it is border management related factors and its subsequent policies that impact on negative attitudes. Negative attitudes are orientated towards policies and the government'actions rather than towards immigrants. It is at this level that we can explain the ambivalence of Spanish public opinion towards immigrants. Now let us focus on the peaks identified in the graph.

The first peak in February 2001 can be attributed to several factors. First, there were important legislative changes, a new immigration law come into force in January 2001 (Ley de extranjeria 8/2000), overturning the recent liberal Law (4/2000) (E. Aja 2006). The law was mainly aimed at fighting illegal immigration, but it also stripped immigrant workers of the rights of association, protest and strike. The law was 
accompanied by a Royal Decree establishing the requirements for the regularization of foreigners able to prove that they were residing in Spain before January 1, 2001. This legislative change affected negative perceptions. Second, as a consequence there were several hunger strikes in Barcelona and sit-ins by illegal immigrants in various regions of the country in order to obtain legal status before the change in law came into effect. A third reason could be the coach accident in Lorca, where 12 undocumented immigrants died. This highlighted the precarious employment situation of many immigrants without residence and work permits. Finally, public figures adopted an alarmist tone on issues of immigration, which might have raised concerns (Zapata-Barrero 2004b, pp. 109-111 and Zapata-Barrero 2003c, pp. 10, 11).

The second peak takes place in June 2002. It is in a period of time where concerns about immigration were high (from May - September 2002 above 20\%). In this period the control of (irregular) immigration was a hot topic on the political agenda. First of all, irregular immigration was one of the priorities of the Aznar government; this became evident in the more restrictive $8 / 2000$ law, but also in the signing of new bilateral agreements with Colombia, the Dominican Republic and Romania to return illegal immigrants. SOS Racismo reported that between May and June there was a massive expulsion of Nigerian immigrants as a consequence of such bilateral agreements (SOS Racismo 2002; 116). A key event in the fight against irregular immigration was the EU Seville Summit under the Spanish Presidency on June 21 and 22, 2002. The basic agreement was to draft restrictive immigration politics to the point of sanctioning the sending countries if they did not demonstrate a will to control their population. The peak of June 2002 can also be understood as growing public concern about immigration, 
in order to put pressure on the Spanish government to place the topic on the European agenda.

In this period, and taking into account multinational character of Spain (Spain has three main minority nations: Catalonia, Basque country and Galicia), immigration also became a contested topic in Catalonia's political agenda, where immigrants were increasingly seen as a threat to the Catalan identity. First, the growing number of Moroccan immigrants settling in Catalonia was interpreted as a national government policy initiative to weaken the autonomy of the Catalan community. Second, there were conflicts related with the Islamic community, as manifested in racist protests against the building of mosques and conflicts over imams. These led the President of the Generalitat (Catalan government) to claim a right to construct a Catalan immigration policy (Anguera 2002; Pérez 2002). ${ }^{14}$

After a period of relatively low concern, there was a general increase starting in September 2004. ${ }^{15}$ The third peak is in April 2005, coinciding with a two-month regularization process adopted by the Spanish government (this time called the "normalization process") to end illegal employment of migrants and attempts to control the black market. On this occasion a new link arises, not so much between legislative change and negative opinion, but among policies regularising by decree. However it is important to note that it was not only the normalization policies itself, but also the political debate that followed and the reactions it raised in the European Union. Many protests and hunger strikes took place in Barcelona by immigrants that could not meet the conditions necessary to benefit from the regularization rounds and claimed to be driven into the hands of exploitative employers (La Vanguardia, 01-05-2005; Safont, $2005 ; 48)$. Another item in the news concerned the growing numbers of undocumented 
Sub-Saharan Africans arriving at the Canary Islands, Ceuta and Melilla. ${ }^{16}$ As reception centres could not take care of all arriving immigrants, flights had to be arranged to transport them to other parts of Spain (Morcillo 2005; 19).

The escalation of events in Ceuta and Melilla coincides with the last three months of 2005, with the highest peak observed in November 2005 (when immigration accounted for $40 \%$ of the responses). As a consequence of the drama at the border, the issue of illegal immigration became again a major topic in Spain's social and political agenda. It is also a priority issue discussed at the Euro Mediterranean Partnership Conference in Barcelona, which took place on the 25th and 26th of November 2005 and at the European Council Summit in Brussels on December 15th and 16th, 2005. This resulted in the EU financing the extension of the Sistema de Vigilancia Exterior (SIVE) to cover the entire Mediterranean region, including the Canary Islands (Missé, 2005; 2). Another reason for this peak were the riots involving immigrant populations in large cities in France, which received a great deal of attention in the Spanish press, as well as the controversial cartoons of Mohammed in September 2005 in the Danish newspaper 'Jyllands Postem.'. Finally, the fifth peak appears in September 2006. The dramatic arrival of undocumented immigrants to the Canary Islands in 2006 made immigration one of the main preoccupations of the Spanish public and placed immigration at the forefront of Spanish and European political agendas. Between January and August, the Islands witnessed a large influx of African immigrants. The arrival of 4,772 immigrants to the Canary Islands in August 2006 broke all previous records. While the majority of immigrants, both regular and irregular, enter Spain by airplane or highway, the images of cayucos arriving to the Spanish Islands and the overcrowded reception centres made immigration the most important problem perceived by the Spanish public in September 
2006 (corresponding to 59.2\%). In order to respond to the large influx of African immigration at the Spanish borderlands and tamper public opinion, the Spanish Socialist government under Prime Minister Rodríguez Zapatero attempted to arrange Returns Agreements with sending countries while at the same time pressing the European Union for help and responsibility to fight illegal immigration. The Spanish governance of EU borders poses normative questions (Zapata-Barrero and de Witte 2007). Here border management, lack of control, governance, and public opinion are directly linked.

\subsection{Significant variables of negative attitude towards immigration}

If we focus on the fourth peak above, the one of November 2005, it also coincides with one of the last special issue survey available concerning immigration. ${ }^{17}$ Immigration is considered to be the second concern (40\%), below unemployment (54\%) and far above ETA terrorism (25.2\%) (question 5). 59.6\% considers that there are too many immigrants (question 6), and the vast majority supports a restrictive policy $(84.7 \%$ are of the opinion that the most suitable policy is that which allows entry only to those with a work contract, question 7). Continuing with the subjects of borders and the perception of how to regulate flows, when asked the question of who one prefers should enter, a majority prefer an immigrant with a work qualification needed in Spain (an average of 6.4/10), a good level of education (an average of 5.6/10) and ability to speak Spanish (or the official language of one of the Autonomous Communities) (an average of 5.2/10). The fact that only just under a $30 \%$ also considers being of Christian faith to be a criterion and that an average of only $1.7 / 10$ requires that they should be white shows that they are not racist. This demonstration of tolerance (non-racism) is not just seen in all of the questions related to identity and emotional matters. Tolerance is also 
related with inclusion policies (equal rights), since $78.9 \%$ express that they "greatly agree" or "agree" that people who have come should have the same rights as the rest (question 9), or, also, people believe that things such as access to education (92.5\%), health care $(81.3 \%)$ should be simplified for immigrants (question 12) and that they should even practise their religion if they so wish $(81.2 \%)$. This tolerance to inclusion policies is even expressed with the support of the right to vote on the local $(60.8 \%)$ and in the general (53.4\%) elections (question 13). With regard to acceptance in different spheres of their day-to-day lives (children's education, work, etc.) responses are also positive (Questions 14-17), even reaching $71.7 \%$ who agree that immigrants should maintain their language and culture (question 20).

We can therefore see that tolerance is expressed at different levels (school, work, etc.), but always related to inclusion and not to issues of frontiers and the management of flows. However this data should be treated with caution given that some studies have shown that this apparent positive tolerance changes in real situations of competition. Thus, it is shown that the socioeconomic logic is also significant. For example, the interesting study by Gimeno (2001, chaps. 5 and pp. 79) concentrates on citizens' perception of competition for access to and the distribution of scarce resources, proving that, if the population had to choose between egalitarian practices towards immigration or access to scarce resources over immigrants, they choose the latter (Gimeno 2001, pp. 879). This shows how negative public attitude usually hierarchizes the distribution of goods and places emphasis on belonging to an identity group.

An initial conclusion is that despite having negative attitudes towards the How many enter (subject of frontiers and migratory flows), survey respondents display a pragmatic attitude to Who enters (personal characteristics of the immigrant, not 
mentioning their nationality and provenance) and a tolerant attitude with regard to equal rights. However all of these opinions are also related with the fact that the perception of the number of immigrants most of the interviewees have is not real (i.e. the "perceived quantity" and the "real quantity" of immigrants is quite different). This is fundamental and confirms the argument that the negative opinion of immigration held on the access level and in relation to how many enters is not so much a real as a perceived issue.

This "perceived reality" is the framework within which we must interpret the other results. In fact, according to table 1 below, $52.4 \%$ of the population has an exaggerated image of the number of immigrants, with $6.6 \%$ of the population believing that over $50 \%$ of the population is immigrant (that half the inhabitants of Spain are immigrants!). On average the responses indicates that, in general, the "perceived amount" is $20.4 \%$, whereas according to Ministerial data in 2005 the "real reality" was $6.2 \%$ or $8.5 \%$ if we take into account the municipal census data or Padrón municipal (11-2005). This case demonstrates that the "perceived amount" is far greater than the "real amount". 18

[Table1 about here]

If we leave to one side the issues related with inclusion and focus on the significant correlations regarding issues related to migratory flows (those that give expression to negative attitudes), we may observe that trends are similar to results highlighted in other transnational studies. Nevertheless, Spain also presents some relevant distinctions, taking into account the literature reviewed in section 1 . Let us look at the most significant by concentrating on two points: question 6 , which focuses its 
attention on the perception of the number of immigrants there are (we collected the percentage of those who said that "there are too many"), and question 10 (above) which deals with the "perceived quantity" (we took the average percentage of the amount of immigrants thought to exist in Spain, and the percentage of those who say they know nothing). ${ }^{19}$

[Table 2 about here]

Several conclusions may be drawn:

1. With regard to the question as to whether they consider there are too many, the conclusions from other studies are confirmed, that variables of age, status, education, ideological scale, condition (especially farmers and pensioners/retired people) are significant, with the exception of sex, although women are usually more negative. These variables are also confirmed in other influential surveys such as the annual Gallup poll of February 2004. ${ }^{20}$

2. In almost all variables there is a lack of proportion between the "real amount" and the "perceived amount". At least two points stand out. First the high percentage of those who confess that they "do not know", which is contradicted by the negative opinions they have. This would corroborate the argument that the negative opinion held of immigration at the access level and with respect to the question of How Many enter, is not so much a real but a perceived reality. Secondly, the disproportion between the real percentage of immigrants (between 6.2 and $8.5 \%$ in 2005 , according to sources) and the perceived percentage (the average oscillating between $14.8 \%$ and $25.3 \%$ ) affects practically all variables without distinction. 
3. There is no exact correlation between the disproportion of the perceived amount of immigrants and the fact that it is perceived that "there are too many". For example, if we take the right-wing ideological variable, there is no such link. They are the ones who perceive a lower number average of immigrants $(14.81 \%)$, but are of the opinion that "there are too many" $(83.8 \%)$. At the other extreme, this can also be seen if we consider age. Young people aged 18-24 believe there to be, on average, $25.35 \%$ of immigrants, but only $54.4 \%$ say that "there are too many".

4. Likewise, the age variable is also significant in the correlation between those who admit they know nothing, and those who are convinced that there are too many of them. $72.1 \%$ of immigrants. $72.1 \%$ of 65 year-olds and above think that "there are too many", but over half say that that they do not know when quizzed on how many they think there are.

5. A correlation between the perception of the number ("there are too many") and the defence of more restrictive policies (only allowing entry to those with a work permit) does not necessarily exist, as already pointed out, among others, by Alvira and García (2002, pp. 191). The November 2005 data show that although the trend is being maintained, it is less intense than other years. $84.7 \%$ were of the opinion that one should "only allow entry to those who have an employment contract" (question 7) and 59.6\% says "there are too many". This means that public opinion does not necessarily link its negative perception ("there are too many") with its defence of a policy "with conditions", which is linked the labour market.

6. Finally, we should not overlook an important point, the high percentage of people who claim they "don't know" when asked about the number of immigrants they think exist. Though the average is $31 \%$, some variables exceed $50 \%$ (age, 
education). This would corroborate the argument that the negative opinion held of immigration is based on a "perceived reality" rather than a "real reality". There are at least two lines of thought that can be explored. The first is that citizens react to phenomenon of immigration with a lack of information. Their response is thus emotional rather than reasoned, and one that leads to many negative attitudes. We should also consider the other extreme, that citizens have a consolidated opinion on certain aspects of immigration, but avoid pronouncing replies that might be interpreted as being "racist" or "politically incorrect".

\section{Conclusions: the ambivalence of Spanish public opinion and the governance hypothesis}

One of the first conclusions is the apparent ambivalence in Spanish public opinion, which shows a negative attitude in relation to levels of flows and frontier related matters, and a positive, tolerant opinion on matters related to inclusion and equal rights. This shows that there is a link between negative attitude and immigration policies, which basically focus on border management. Thus a connection must exists between the political agenda and the issues that are most rebuffed by citizens.

We can argue that the specific factors that influence in the "problematisation" of immigration are ultimately linked to the legislative changes and the perception of ineffective management of flows. It is here where the ambivalence of Spanish public opinion can be understood. Within this interpretative framework, three relevant distinctive arguments exist. 
Firstly, perhaps Spain offers a new variable for consideration. It is not so much the actual volume of migratory flow itself that influences promotion of negative attitude, but rather its growth rate: $:^{21}$ from 2000 to 2005 there was an increase of $3.5 \%$. Secondly, the tolerant attitude shown with regards to inclusion is a symptom that we are at the start of the process where citizens' opinion is shaped more by border matters than coexistence. At this level, we could say that a link exists between policies focusing on borders and the orientation of the citizens' negative perception. This means that, if policies begin to focus on coexistence, equal rights and inclusion, then supposedly the focus of public opinion will divert, and this would start to generate, we propose as a hypothesis, a negative attitude. To this end, the apparent "tolerant attitude" that all studies highlight and is also expressed in the November 2005 Barometer, reflects an unfounded public opinion since there is no political management reference point on these issues in which to base their opinion. In other words, as the government does not have any explicit policies of inclusion (or at least does not reveal them to the citizen) whereas it does have them for border management, public opinion has no empirical reference point on which to base its attitude. Along this line of reflection, we uphold that in Spain attitudes towards immigration should not only be interpreted in a framework in which the immigration phenomenon is assessed, but also on the implementation of policies and the government's capacity to respond to citizens' uncertainties.

However all of these opinions must also be related with the fact that most of those interviewed have an unreal perception of the number of immigrants that actually exist in Spain with the perceived quantity and the real quantity of immigrants being quite different. What makes the Spanish case so interesting is that it highlights not only ambivalences in public opinions, showing how "what the government does" and "what 
the citizen perceive" are linked, but also that issues related to immigration are more a matter of interpretation than a matter of fact. It is at this point that maybe we can formulate the governance hypothesis:: the negative attitude of citizens is not so much directed at immigration, but at the Government (and policies) and its (in)capacity to govern issues related to immigration and to respond to citizens' expectations. This governance hypothesis allows us to understand the ambivalence there is in Spain when border and integration issues are compared. But this can be the second step of this line of research.

\section{Bibliographical References}

AJA, ELISEO. 2006 'La evolución de la normativa sobre inmigración en España’, in E. Aja and J.Arango eds. Veinte años de inmigración en España, perspectivas jurídica y sociológica [1985-2004] Barcelona: Fundación CIDOB, pp.17-44.

ALVIRA MARTÍN, F. and GARCÍA LÓPEZ, J. 2003 'Opinión pública e inmigración', in Papeles de economia española, 98, pp.182-197

BAUER, T. K., LOFSTROM, M. and ZIMMERMANN, K. L. 2000 'Immigration policy, assimilation of immigrants and natives' sentiments towards immigrants : evidence from 12 OECD-Countries', IZA-Discussion Paper n ${ }^{\circ} 187$ August, Bonn Institute for the Study of Labor

BECK, R. and CAMAROTA, S. A. 2002 'Eliste vs. Public opinión: an examination of divergent views on immigration', Center for migration studies, December

BERINSKY, ADAM J. 2005 Silent Voices. Princeton, NJ: Princeton University Press

BLOMMAERT, J. and VERSCHUEREN, J. 1998: Debating diversity. Analysing the discourse of tolerance, Routledge, London. 
BORJAS, GEORGE 1999 Heaven's door: immigration policy and the American economy, Princeton: Princeton University Press

BURNS, P. and GIMPEL, J. G. 2000 'Economic insecurity, prejudicial stereotypes, and public opinion on immigration policy', Political Science Quaterly, vol. 115, nº 2, pp. 201-205.

CACHÓN, LORENZO 2005 Bases sociales de los sucesos de Elche de septiembre de 2004. Madrid: Ministerio de Trabajo y Asuntos Sociales Secretaria de Estado de inmigración y emigración

CAMPO LADERO, MARÍA J. 2004, Opiniones y actitudes de los españoles ante el fenómeno de la inmigración, CIS, Madrid. Colección Opiniones y Actitudes, $\mathrm{n}^{\circ} 48$.

CEA D’ANCONA, MARÍA A. 2004, La activación de la xenofobia en España. ¿Qué miden las encuestas ?, Madrid, CIS

CITRIN, J., GREEN, D. P., MUSTE, CHR. and WONG, C. 1997 'Public opinión towards immigration reform: the role of economic motivations', The Journal of Politics, vol. 59, no 3, pp. 858-881.

CITRIN, J., SEARS, D. O., MUSTE, Chr. and WONG, C. 2001 'Multiculturalism in American Public Opinión', Bristish Journal of Political Science, 31, 247-275.

COENDERS, M. 2001 Nationalistic Attitudes and Ethnic Exclusionism in a Comparative Perspective: An Empirical Study of Attitudes Toward the Country and Ethnic Immigrants in 22 countries ICS dissertation, Commissioned by: -, Nijmegen

COENDERS, M., LUBBERS, M. and SCHEEPERS, P.L.H. 2004 Majority populations' attitudes towards migrants and minorities, Ref. n 2003/04/01 Reports 1-4, Brussels: European Monitoring Centre on Racism and Xenophobia 
COLECTIVO IOE 2005 'Ciudadanos o intrusos: la opinión pública española ante los inmigrantes', Papeles de Economía Española, 104, pp. 194-209

CORNELIUS, W. A. and ROSENBLUM, M. R. 2004 'Immigration and Politics' Annu. Rev. Political Science, 08, pp. 99-119

CORNELIUS, W. A., TSUDA, T., MARTIN P.L and HOLLIFIELD J.F. 2004 Controlling immigration: a global perspective, Standford: Stanford University Press. DÍEZ NICOLAS, JUAN 2006 Las dos caras de la inmigración, Madrid: Madrid: Ministerio de Trabajo y Asuntos Sociales Observatorio Permanente, $\mathrm{n}^{\circ} 3$

FETZER, Joel S. 2000 Public Attitudes toward Immigration in the United States, France, and Germany, Cambridge University Press

GIMENO, LEONOR 2001 Actitudes hacia la inmigración, Madrid: Centro de Investigaciones Sociológicas n. 34

HUNTINGTON, SAMUEL P. 2004 Who are We?: The Challenges to America's National Identity, New York: Simon \& Schuster.

IZQUIERDO, ANTONIO. 1996 La inmigración inesperada, Madrid: Trotta.

KESSLER, A. E. and FREEMAN, G. P. 2005 'Public Opinion in the EU on Immigration from outside the Community', Journal of Common Market Studies, vol. 43 , issue 4 , pp. $825-850$

LAHAV, GALLYA 2004a Immigration and Politics in the New Europe Reinventing Borders Cambridge University Press, Cambridge

LAHAV, GALLYA 2004b 'Public opinion toward immigration in the European Union. Does it matter?', Comparative political studies, vol. 37, n. 10, December, pp. 11511183 
LAHAV GALLYA and GUIRAUDON, VIRGINIE 2006 'Actors and venues in immigration control: Closing the gap between political demands and policy outcomes', West European Politics, vol. 29, n 2, pp. 201-223

LUEDTKE, A 2005 'European integration, public opinion and immigration policy Testing the impact of national identity', European Union Politics, vol. 6, n⿳⺈ 1, pp. 83-112

MACLAREN, LAUREN 2001 'Immigration and the new politics of inclusion and exclusion in European Union', European Journal of Political Research, n 39, pp. 81-108

MÉNDEZ LAGO, MÓNICA 2006 'La Opinión Pública ante el tema de la inmigración: Resumen de los resultados del Barómetro de Noviembre 2005 del CIS' Mimeo, Centro de Estudios Políticos y Constitucionales

OLIVER, J. E. and WONG, J. 2003 'Intergroup prejudice in multiethnic settings', American Journal of Political Science, vol. 47, nº 4, pp. 567-582.

PÉREZ-DÍAZ， VICTOR， ÁLVAREZ-MIRANDA， BERTA. and GONZÁLEZENRÍQUEZ, CARMEN 2002 España ante la inmigración, Fundación 'la Caixa', Colección Estudios Sociales, vol. 8

SAGGAR, SHAMIT 2003 'Immigration and the politics of public opinion', The Political Quaterly,

SIMON, R. J. and LYNCH, J. P. 1999 'A comparative assessment of Public opinión toward immigrants and immigration policies', Internacional Migration Review, vol. 33 (2), pp. 4555-467.

SOS RACISMO 2002, Informe Annual sobre el Racismo en el Estado español Barcelona: Icaria 
TERRÉN, E. 2004 'Opinión pública visibilidad: las encuestas sobre racismo y xenofobia', en Bernabé López Garcia and Mohamed Berriane, Atlas de la inmigración marroquí en España Madrid: Taller de Estudios Internationales Mediterráneos TEIM, Universidad Autonóma de Madrid, pp. 439-441.

VALLES, MIGUEL et. al. 1999 Las encuestas sobre inmigración en España y Europa, Madrid: Observatorio Permanente de la Inmigración (OPI), Imserso.

VAN DIJK, TEUN 2003a Dominación étnica y racismo discursivo en España y America Latina, Barcelona: Gedisa

-- 2003b Racismo y Discurso de las Élites, Barcelona, Gedisa

ZAPATA-BARRERO, RICARD 2003a 'The 'Discovery' of Immigration: The Politicization of Immigration in the Case of El Ejido', Journal of International Migration and Integration, 4/4, pp. 523-539

-- 2003b 'Spain', In J. Niessen, and Y. Schibel eds, EU and US approaches to the management of immigration: comparative perspectives 1-30. Brussels: Migration Policy Group

-- 2004a Multiculturalidad e inmigración, Madrid: Ed. Síntesis

-- 2004b Inmigración, innovación política y cultura de acomodación en España, Barcelona: Fundació CIBOB

-- 2006 'The Muslim Community and Spanish Tradition: Maurophobia as a Fact, and Impartiality as a Desiratum', In Modood, T., Triandafyllidou, A., and ZapataBarrero, R. eds. Multiculturalism, Muslims and citizenship: a European approach New York: Routledge cap. 8, pp. 143-161. 
-- 2007a "Immigration, self-government and management of identity: the catalan case"

M. Korinman y J. Laughlan (eds.) The long march to the west. Middleesex: Vallentine Mitchell Academic, pp. 179-202.

-- 2007b "Política del discurso sobre inmigración en España: discurso re-activo y discurso pro-activo en los debates parlamentarios", Discurso \& Sociedad, vol. 12, pp. 294--339 http://www.dissoc.org/ediciones/v01n02/ DS12Zapata.html

-- 2008a Inmigración en naciones minoritarias, Barcelona: Icaria

-- 2008b Fundamentos de los discursos políticos en torno a la inmigración, Madrid: Trotta (forthcoming)

ZAPATA-BARRERO, RICARD and WITTE, NYNKE de 2007 'The Spanish Governance of EU Borders: Normative Questions', Mediterranean Politics, vol. 12/1, March, 85-90

ZAPATA-BARRERO, RICARD and QASEM, ISLAM 2008 'The politics of discourse towards Islam and Muslim communities in Europe', P. Mouritsen and K. E. Jørgensen eds. Constituting Communities: Political Solutions to Cultural conflict, Hampshire: Palgrave Macmillan, pp. 73-93.

\section{Internet resources (surveys and reports)}

CIS: CENTRO DE INVESTIGACIONES SOCIOLÓGICAS: http://www.cis.es

GLOBAL COMMISSION ON INTERNATIONAL MIGRATION (GCIM) (2005) Las migraciones en un mundo interdependiente: nuevas orientaciones para actuar Migrations in an interdependent world: new orientations for action http://www.gcim.org/mm/ File/Spanish(1).pdf

EUROBAROMETER: http://ec.europa.eu/public_opinion/standard_en.htm 
GALLUP (Survey) (2004) "Perception of Immigration in Spain: over half of Spaniards considers that Spain receives more immigrants than it can”, http://www.gallup.es/notasp /nota48.asp

REPORT BY THE SECRETARY GENERAL OF THE UNITED NATIONS (2006) International migration and development. Sixtieth period of sessions Theme $54 \mathrm{c}$ ) of programme Globalisation and interdependence: international migration and development. $\quad$ http://www.un.org/esa/population/hldmigration/Text/Report\%20of \%20the\%20 SG\%20\%28June\%2006\%29_Spanish.pdf

INTERNATIONAL ORGANIZATION FOR MIGRATION (IOM) (2004) The image of immigrants in Society, 18 November MC/INF/277

\section{Press cited}

ANGUERA, I. (2002) "Los partidos catalanes rompen la breve tregua en torno a la inmigración” $A B C, 31$ May

LA VANGUARDIA (2005) "La huelga de hambre que siguen 170 inmigrantes se mantendrá hasta el sábado" 1 May

MISSÉ, A. (2005) "La UE pagará un sistema de control migratorio en todo el Mediterráneo, Los 25 crearán un fondo para la integración de inmigrantes promovido por Zapatero", El País, 12 December: 2

MORCILLO, C. (2005) “Los vuelos de «sin papeles» hacia la Península se extienden desde Ceuta y Melilla tras solicitarlo el PP al Gobierno", $A B C, 1$ April: 19 
PÉREZ, M. (2002) "La alcaldesa de Premià pide ayuda a los gobiernos ante los brotes de racismo por la futura mezquita Jordi Pujol reclama más competencias para hacer una política de inmigración diferenciada", El País, 21 May

SAFONT, C. (2005) "Protesta de 200 guineanos por el elevado coste del certificado de penales" La Vanguardia, 10 Abril; 48

\section{Contact Details}

RICARD ZAPATA-BARRERO is Assistant Professor in the Department of Social and Political Science at Universitat Pompeu Fabra (Barcelona)

ADDRESS: Department of Social and Political Science, Universitat Pompeu Fabra, Ramon Trias Fargas, 25-27, 08005 Barcelona, Spain. Email: ricard.zapata@upf.edu 
Notes

* Some parts of this chapter have been presented in epsNet Annual Conference (Ljubljana, 22-23 June 2007), Centre de Recherche sur les Identités Nationales et l'Interculturalité (CRINI) (Université de Nantes, France, 19 may 2007) and the Institut Nationale d'Etudes Demographiques (INED) (Paris, 15 january 2007). I would like to thanks all who have contributed by their comments to the final draft.

1 Studies on opinions in Europe usually use the Eurobarometer surveys (ec.europa.eu/public_opinion/standard_en.htm) both in general and those that were carried out specifically on immigration in 1988, 1993, 1997 and 2000, and the European Social Survey: http://ess.nsd.uib.no/index.jsp). Notable recent influential reports are: International Organization for Migration (IOM) (2004); Global Commission on International Migrations (CGMI) (2005), Report by the Secretary General of the United Nations (2006).

${ }^{2}$ Cornelius and Rosenblum, for example, follow this line of argument. For them: "Evidence suggests that "real or perceived" is an important distinction, as public attitudes about immigration reflect substantial misconceptions, though at least some of these apparent misconceptions actually reflect citizens' tendency to respond to migration on emotional (or affective) levels rather than on the basis of objective self-interest or personal experience" (2004, pp. 102-103)

${ }^{3}$ Either "indifferent", or "does not know, does not respond". What is significant is that in some questions "Does not know" exceeds 50\%, as we shall see later. To explain this is beyond the reach of this article but this requires surely the consideration of at least 
two lines of thought: a lack of information or constrains by social desirability (avoiding openly pronouncing responses which could either be interpreted as being "racist" or "politically incorrect"). We should also consider the influence of ambivalence (see, for instance, the work of Berinsky 2005).

${ }^{4}$ I am basing myself on the results of territorially and temporally localised studies, as well as transnational and temporal regressive comparative analysis. Among others, Simon and Lynch (1999), Fetzer (2000), Burns and Gimpel (2000), Mclaren (2001), M. Coenders (2001), Beck and Camarota (2002), Saggar (2003), Lahav (2004a, 2004b); Coenders et. al. (2004) Kessler and Freeman (2005), Luedtke (2005).

${ }^{5}$ For further discussion, see Oliver and Wong (2003), Burns and Gimpel (2000), the transversal analysis of the Eurobarometer and the European Social Survey of Coenders et. al. (2004), and Kessler and Freeman (2005).

${ }^{6}$ What it is known as the gap hypothesis, first stated by W. A. Cornelius et al. (2004) and then, also applied by Lahav and Guiraudon (2006).

${ }^{7}$ See, among others, Valles, Cea and Izquierdo (1999), Pérez Díaz et al. (2002), Alvira Martín and García López (2003), Campo Ladero (2004), Colectivo IOE (2005), Díez Nicolas (2006).

${ }^{8}$ According to data from the Annual statistics on Foreigners 1996-2004 (December 31) and the Statistical Report dated 31-12-2005, by the Ministry of Labour and Social Affairs and the National Statistics Institute, municipal Census 1995-2005, in 2000, the immigrant population was 895,720 and in 2005 it was $2,738,932$. This is a $3,5 \%$ increase in five years. 
9 The CIS (www.cis.es) is an independent entity established to study Spanish society, mainly through public opinion polls. It is assigned by the Ministerio de la Presidencia (Ministry of the Presidency). The monthly held "barometers" by the CIS measure public opinion in Spain in relation to the political and economic situation of the country. For more detailed information see http://www.cis.es

${ }^{10}$ We begin to have a very extensive record of surveys over time. The first surveys, which exclusively deal with attitudes towards immigration, date from 1990, in March by the CIRES (Centro de Estudios sobre la Realidad Social or Centre for Research on Social Reality) and in September by the CIS. For a list of the surveys carried out in Spain, please see Cea D’Ancona (2004, pp.1-9)

11 This is the reading followed by Zapata-Barrero (2003b, pp. 10 and 2004b, pp.108116).

12 The ranking of "immigration" in relation to the frequency it is chosen over other answers defined in advance can be found between brackets on the x-axis.

13 The relatively low numbers (below 10\%) in November/ December 2001 and March/ April 2003 are mainly a result of concerns about ETA terrorism and in March 2004 due to the terrorist attacks in Madrid.

14 See the first reflections in Zapata-Barrero (2007a), and key comparisons in ZapataBarrero (2008a)

${ }^{15}$ We can mention the events in Elche, a traditionally shoe-making town in the coastal province of Alicante, where Spanish workers set fire to two Chinese shoe warehouses during an (unauthorized) demonstration against Chinese shoemakers involving nearly half a thousand people. The demonstrators protested against the presence of Asian 
businessmen. Spaniards felt their age-old social customs, employment norms, and labor relations were threatened by the new competitors with racism as an effect (see also L. Cachón-Rodríguez 2005).

${ }^{16}$ Spain also has land borders with Morocco in the Ceuta and Melilla enclaves, on the North African coast. Some $25 \mathrm{~km}$ from continental Europe across the Strait of Gibraltar lies the ancient port and fortified town of Ceuta,. Some $250 \mathrm{~km}$ to the east, stands the town of Melilla. Increased border controls and improved diplomatic relations between the Zapatero administration and Morocco have resulted in the development of a new immigration route since January 2006 between the African West Coast and the Canary Islands (see Zapata-Barrero and deWitte 2007).

17 Sample data are 2500 interviews (2485 effectively realised) at national level and throughout all the Spanish territory. For more technical details, see www.cis.es (barometer 2625).

${ }^{18}$ It should also be stressed that $31 \%$ prefer not to comment, expressing a doubt as to the number of immigrants that exists.

${ }^{19}$ In table 2 below, I have included the significant variables. For a complete list please see $\underline{\text { wWw.cis.es. }}$

${ }^{20}$ http://www.gallup.es/notasp/nota48.asp

${ }^{21}$ This is also the argument about Hispanic immigration to the USA of Huntington's (2004) controversial and very high-profile book. A good part of his argument exactly deals with issue of the pace and combined with the number of immigrants. For him, the persistent inflow of Hispanic immigrants threatens to divide the USA into two peoples, two cultures, and two languages, and is challenging directly "American identity". 
Graph 1. Trends in Spanish concerns about immigration. Answers to the question: According to you, what is the most important problem facing our country today?

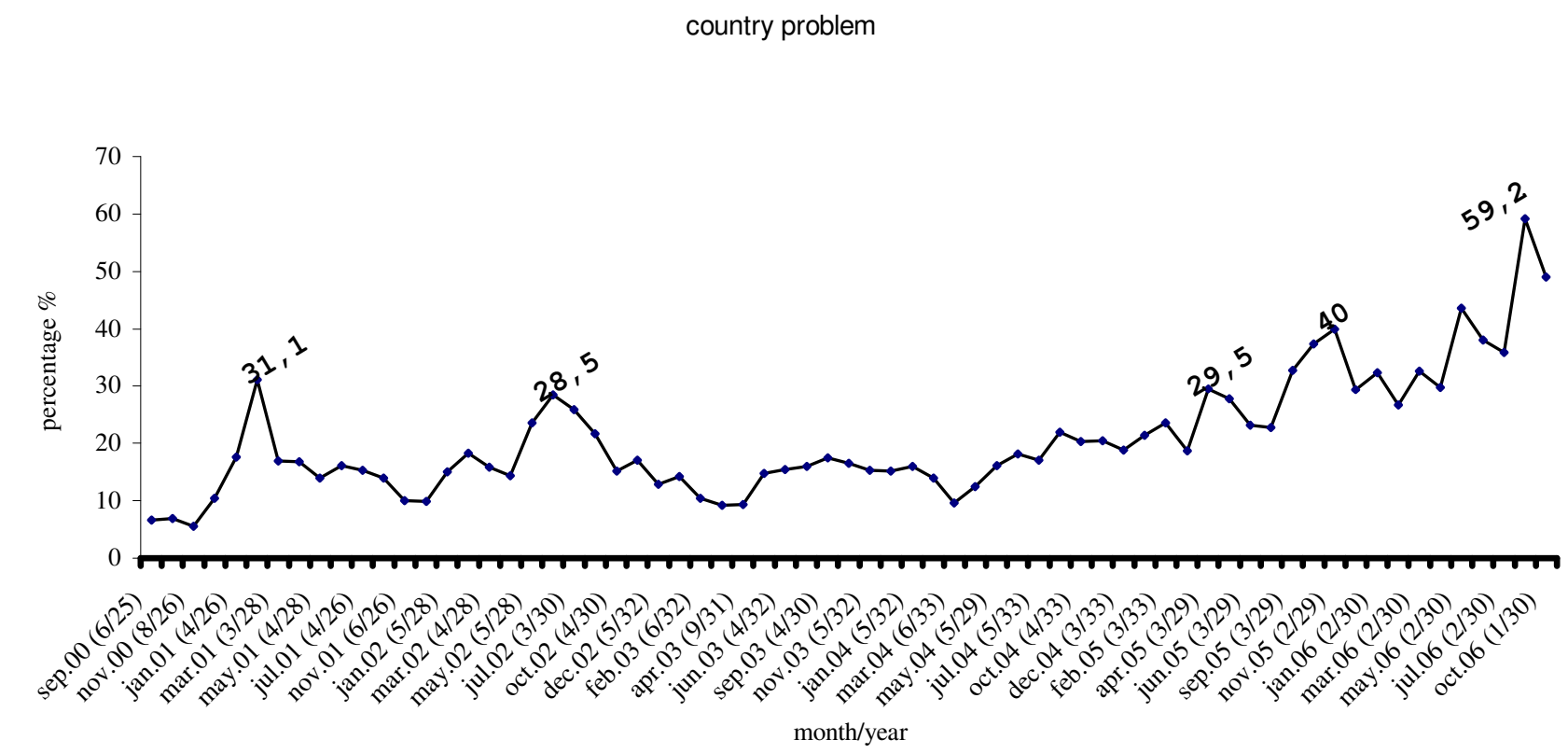

Source: Barómetros del Centro de Investigaciones Sociológicas (CIS), September 2000 - October 2006 (estudios 2398 -2657). Note: Barometers are not held in the month of August. October 2001 is missing because this questionnaire was dedicated to the terrorist attacks in New York on September 11. The ranking of "immigration" and the total number of frequent given answers defined in advance can be found in brackets on the $\mathrm{X}$-axis 
Table 1: Question 10: Of every 100 people living in Spain, how many do you think were born outside the country?

\begin{tabular}{|c|c|}
\hline \multicolumn{1}{|c|}{} & $\%$ \\
\hline Less than 10 people & 15.9 \\
\hline $\mathbf{2 0 - 2 9}$ & 20.5 \\
\hline $\mathbf{3 0 - 3 9}$ & 13.1 \\
\hline $\mathbf{4 0 - 4 9}$ & 8.0 \\
\hline $\mathbf{5 0}$ or more people & 6.6 \\
\hline Don't know & 31.0 \\
\hline No reply & 0.6 \\
\hline TOTAL & 100.0 \\
\hline
\end{tabular}


Table 2: Significant variables with regard to negative attitudes ("there are too many" and averages for "perceived amount" of immigration.

\begin{tabular}{|c|c|c|c|}
\hline & & $\begin{array}{c}\text { Question } 6 \\
\% \text { who reply "there are } \\
\text { too many" }\end{array}$ & $\begin{array}{l}\text { Question } 10 \\
\text { mean } \% \text { of immigrants believed to exist in Spain, and } \\
\% \text { of replies saying they Don't know }\end{array}$ \\
\hline \multirow{5}{*}{ 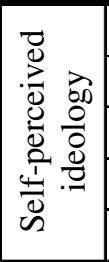 } & Right (9-10) & 83.8 & 14.81 and $43.2 \%$ "Don't know" \\
\hline & $(7-8)$ & 71.5 & 20.10 and $29.4 \%$ "Don't know" \\
\hline & $(5-6)$ & 58.2 & 18.89 and $27.5 \%$ "Don't know" \\
\hline & $(3-4)$ & 52.0 & 18.70 and $25.8 \%$ "Don't know" \\
\hline & Left (1-2) & 43.2 & 19.81 and $21.9 \%$ "Don't know" \\
\hline \multirow{5}{*}{ 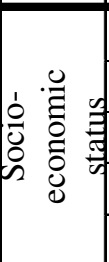 } & Unskilled workers & 67.6 & 23.38 and 38\% "Don't know" \\
\hline & Skilled workers & 65.5 & 21.90 and $33.4 \%$ "Don't know" \\
\hline & Classic middle classes & 67.2 & 18.24 and $37.7 \%$ "Don't know" \\
\hline & New middle classes & 55.6 & 22.25 and $24.1 \%$ "Don't know" \\
\hline & Upper/upper-middle classes & 42.7 & 15.97 and 23.5\% "Don't know" \\
\hline \multirow{6}{*}{ 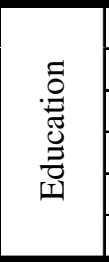 } & Unqualified & 73.8 & 19.87 and $65.6 \%$ "Don't know" \\
\hline & Primary & 67.9 & 22.93 and 35.9\% "Don't know" \\
\hline & Secondary & 54.6 & 19.47 and $20.3 \%$ "Don't know" \\
\hline & Vocational Training & 57.9 & 21.72 and $22.7 \%$ "Don't know" \\
\hline & University diploma & 39.2 & 15.34 and $17.1 \%$ "Don't know" \\
\hline & Higher & 32.9 & 15.35 and $14.8 \%$ "Don't know" \\
\hline \multirow{2}{*}{ ひ } & Female & 62.6 & 23.65 and $36.8 \%$ "Don't know" \\
\hline & Male & 56.5 & 17.58 and $25 \%$ "Don't know" \\
\hline \multirow{6}{*}{$\stackrel{80}{<}$} & From 18 to 24 & 54.4 & 25.35 and $21.3 \%$ "Don't know" \\
\hline & From 25 to 34 & 54 & 21.96 and $19.3 \%$ "Don't know" \\
\hline & From 35 to 44 & 56.5 & 19.14 and $24.8 \%$ "Don't know" \\
\hline & From 45 to 54 & 56.6 & 18.53 and $28.2 \%$ "Don't know" \\
\hline & From 55 to 64 & 61.9 & 17.06 and 31.9\% "Don't know" \\
\hline & From 65 and over & 72.1 & 19.92 and $55.6 \%$ "Don't know" \\
\hline \multirow{11}{*}{ 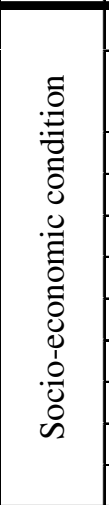 } & Managers and professionals & 48 & 16.61 and $16.7 \%$ "Don't know" \\
\hline & $\begin{array}{l}\text { Technicians and middle } \\
\text { management }\end{array}$ & 39.6 & 16.63 and $18.9 \%$ "Don't know" \\
\hline & Small businesspeople & 57.8 & 17.03 and $25.6 \%$ "Don't know" \\
\hline & Farmers & 72.4 & 18.22 and 34.5 "Don't know" \\
\hline & Office and service employees & 51.3 & 22.62 and $19.2 \%$ "Don't know" \\
\hline & Skilled workers & 61.6 & 19.53 and $25.1 \%$ "Don't know" \\
\hline & Unskilled workers & 62.7 & 23.92 and $23 \%$ "Don't know" \\
\hline & Retired and pensioners & 71.2 & 19.84 and 47.3 "Don't know" \\
\hline & Unemployed & 59.7 & 22.56 and 24.2 "Don't know" \\
\hline & Students & 35.5 & 20.14 and 15.1 "Don't know" \\
\hline & Unpaid work in the home & 67.1 & 22.16 and 47.2 "Don't know" \\
\hline
\end{tabular}

